\title{
8-2 テープ
}

\section{1. ま がき}

テレビ放送の音声が生番組を除いてほとんどすべて俭 気テープに録音された再生音であるという現状からいっ て，磁気記録再生の品質に影響する磁気テープの素材に ついてふれておくことも必要と思われる。テレビ信号の 記録用磁気テープに関する論文，資料は，彷来主として 画像記録にその勢力が注がれていた傾向があったが，今 回はテーマに示すようにテレビ音声記録用媒体としての 磁気テープという観点から少しく述べたいと思う。

\section{2. 磁気記録テープの構造}

合金薄膜形テープは別として, 磁気記録テープは支持 "2. Recording Tapes" by Koshu Kurokawa (Fuji Photo Film Co., Ltd., Odawara, Kanagawa)
窑士貲フィルム株式会社黑川行修
を用いて塗着してある。図1亿現在実用されている磁気 テープの構造を, 表1に各種テープの実際の厚さ配分を 示した.

\section{3. 磁気テープの音声特性に影響を与える} \section{諸因子}

表 2 は音声特性に影響する設計上, 製造上の要因につ いてまとめたものである.との表から磁気テープの音声 特性に限定してあ，かなり䈌しいバランスを必要とする

表 1 各種磁䒝テープ (音声記録) の厚さ配分

\begin{tabular}{|c|c|c|c|c|c|c|c|c|c|}
\hline 品 & 琶着機器 (タイプ) & 用 途 & 幅 (in) & 全 厚 & $\begin{array}{c}\text { 磁性曆 } \\
(\mu \mathrm{m})\end{array}$ & $\begin{array}{c}\text { バック層 } \\
(\mu \mathrm{m})\end{array}$ & $\begin{array}{c}\text { ベース層 } \\
(\mu \mathrm{m})\end{array}$ & ベース材質 & 備 \\
\hline ビデガテープ & $\begin{array}{c}4 \text { ヘッド VTR } \\
\text { MAVTR } \\
\text { ヘリカルVTR }\end{array}$ & $\begin{array}{l}\text { 放 䢠用 } \\
\text { 音声編集 } \\
\text { 一 般 用 }\end{array}$ & $\begin{array}{c}2 \\
2 \\
1,3 / 4,1 / 2\end{array}$ & $\begin{array}{l}34 \sim 38 \\
34 \sim 38 \\
20 \sim 30\end{array}$ & $\begin{array}{c}10 \sim 12 \\
10 \sim 12 \\
4 \sim 6\end{array}$ & $\begin{array}{c}(2 \sim 3) \\
- \\
(2 \sim 3)\end{array}$ & $\begin{array}{l}20 \sim 24 \\
20 \sim 24 \\
16 \sim 24\end{array}$ & $\begin{array}{l}\text { P E T } \\
" \prime \\
\prime \prime\end{array}$ & $\begin{array}{l}\text { 最近, カーボンブラ } \\
\text { ックを含んだバック } \\
\text { 層を施ししたテープ } \\
\text { むむる. }\end{array}$ \\
\hline 磁文、フィルム & $\begin{array}{r}35 \mathrm{~mm} \text { シネコーダー } \\
17.5 \mathrm{~mm} \text { シネコーダー } \\
16 \mathrm{~mm} \text { シネコーダー }\end{array}$ & $\begin{array}{l}\text { 肤画 用 } \\
\text { テレビ用 } \\
\text { テレビ用 }\end{array}$ & $\begin{array}{r}35 \mathrm{~mm} \\
17.5 \mathrm{~mm} \\
16 \mathrm{~mm}\end{array}$ & $\begin{array}{c}140 \sim 150 \\
" \\
" \\
135 \sim 140 \\
85 \sim 90\end{array}$ & $\begin{array}{c}14 \sim 16 \\
" \prime \\
11 \sim 13 \\
\prime \prime\end{array}$ & $\begin{array}{l}- \\
-\end{array}$ & $\begin{array}{c}12.5 \sim 130 \\
" \prime \\
" 1 \\
75\end{array}$ & $\begin{array}{c}\text { TAC } \\
" \\
\text { P E T }\end{array}$ & $\begin{array}{l}\text { 主に外国で使われて } \\
\text { いる. }\end{array}$ \\
\hline $\begin{array}{c}\text { オーディオテープ } \\
\vdots\end{array}$ & $\begin{array}{l}100 \% \text { タイプ } \\
150 \% \text { タイプ } \\
200 \% \text { タイプ } \\
\text { エンドレスタイプ } \\
\text { カセット C }-60 \\
\text { C }-90 \\
\text { C }-120\end{array}$ & \begin{tabular}{c|} 
一般 赒 \\
長時間 \\
超長時間 \\
カートリッジ \\
一般用 \\
長 時間 \\
超長時間
\end{tabular} & $\begin{array}{c}1 / 4,1 / 2 \\
1 / 4 \\
" \\
" \prime \\
3.8 \mathrm{~mm} \\
" \prime \\
\prime \prime\end{array}$ & $\begin{array}{c}45 \sim 53 \\
31 \sim 39 \\
20 \sim 29 \\
35 \sim 40 \\
15 \sim 19 \\
10 \sim 13 \\
8 \sim 9\end{array}$ & $\begin{array}{c}10 \sim 12 \\
9 \sim 11 \\
6 \sim 8 \\
10 \sim 12 \\
5 \sim 6 \\
4 \sim 5 \\
3 \sim 4\end{array}$ & $\begin{array}{c}(2 \sim 3) \\
" \\
- \\
1 \\
- \\
- \\
-\end{array}$ & $\begin{array}{c}35 \sim 38 \\
20 \sim 25 \\
15 \sim 17 \\
21 \sim 25 \\
12 \\
8 \\
6\end{array}$ & $\begin{array}{c}\text { TAC, PVC } \\
\text { DAC } \\
\text { PE T } \\
" \\
\text { " } \\
\text { 再延伸 PET } \\
\text { " } \\
"\end{array}$ & $\begin{array}{l}\text { マスタータイプの- } \\
\text { 部にバック層を施て } \\
\text { したものもある. }\end{array}$ \\
\hline
\end{tabular}

表 2 音声特性に影響を与える設計，製造の諸园子

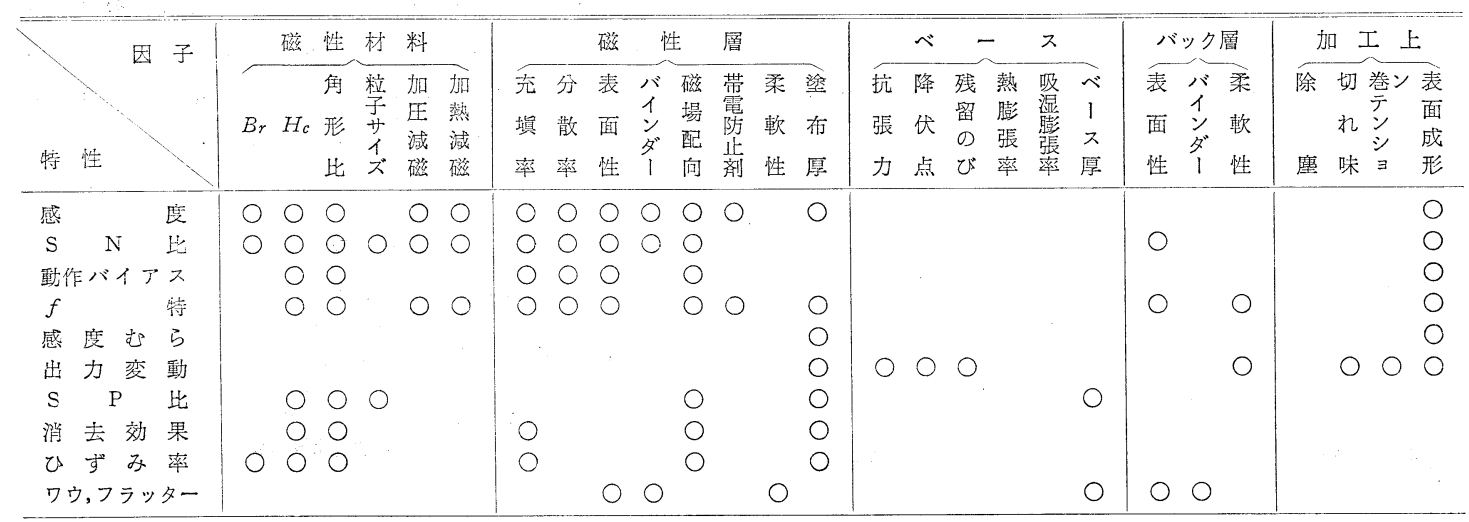


ととが理解される。

表 2 に示した特性要因のなかから，と くに磁性体についてその種類別に検討し ておきたい

一般的にいって磁気記録用に好適な磁 気特性としては，次の各項があげられ る.

（i）最大残留磁束密度 $B_{r \max }$ 值が大 きいこと.

(ii) $B-H$ 曲線が急峻であること. いいかえれば， $(\Delta B / \Delta H)_{\max }$ 值が 大きいとと。

（iii）抗磁力 $H_{c}$ は周波数特性, 転写効果からの各要 求を満たすために適当な值であること.

(iv) 粒子サイズは $1 \mu \mathrm{m}$ 以下であること.

（v）粒子間の $H_{c}$ 值の分布が鋭く, 低い $H_{c}$ 成分 が混入していないとと.

これを概念図的に示すと図 2 のようになり，材料的に はIがIIよりずれていることになる。乙こで注意すべ きととは，粉末磁性材料の特性は個々の粒子が統計的に 総合されたものである点である。すなわち，

(a) 各粒子間の磁化特性の分布

（b）各粒子配向 (orientation) の分布

などが総合されて見かけ上の磁性粉集合体の磁化特性が 決定されるのである。このような諸条件を満たすため に，記録用磁性材料についての研究が各国で熱心に行な われてきたが，それらの磁性材料を大別すると表 3 のよ うになる。

現在, 実際に市販されている磁気テープ用の磁性体と しては，酸化鉄系の $\gamma-\mathrm{Fe}_{2} \mathrm{O}_{3}$ 粒子および非鉄金属酸化 系の $\mathrm{CrO}_{2}$ 粒子である，それぞれについて特徽をあげる と次のようになる.

(1) ゲーサイト法による $\gamma-\mathrm{Fe}_{2} \mathrm{O}_{3}$

（a） ${ }_{i} H_{c}$ の調節範囲は $180 \sim 350$ Oe で比較的狭 いが，一定の反㤂条件に対して安定している.

(b) $B_{r} /_{i} B_{m}$ 值屯磁界配向を加えれば 0.8 にも達

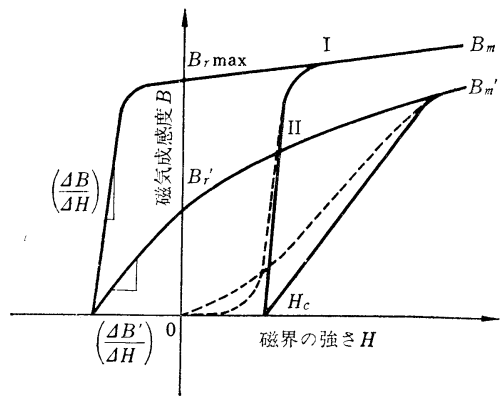

図 2 磁性体の磁化曲線
表 3 磁気記録用磁性材料の分類

\begin{tabular}{|c|c|c|}
\hline 類 & 組 & 備 \\
\hline 系 & $\gamma-\mathrm{Fe}_{2} \mathrm{O}_{3}, \quad \mathrm{Fe}_{3} \mathrm{O}_{4}$ & $\begin{array}{l}H_{c}=250 \sim 3500 \mathrm{Oe} \\
B_{m}=5,000 \sim 6,000 \text { gauss* }\end{array}$ \\
\hline 比鉄系 & Co 含有 $\gamma-\mathrm{Fe}_{2} \mathrm{O}_{3}, \mathrm{Fe}_{3} \mathrm{O}_{4}$ & $\begin{array}{l}H_{c}=\sim 1,000 \mathrm{Oe} \\
B_{m}=5,000 \sim 7,000 \text { gauss* }\end{array}$ \\
\hline 属系 & $\mathrm{CrO}_{2}(\mathrm{Sb}, \mathrm{Te})$ & $\begin{array}{l}H_{c}=\sim 6000 \mathrm{e} \\
B_{m}=\sim 7,000 \text { gauss* }\end{array}$ \\
\hline 系 & $\mathrm{Fe}-\mathrm{Co}-\mathrm{Ni}, \mathrm{Fe}-\mathrm{Co}-\mathrm{Cu}, \mathrm{Co}-\mathrm{Ni}$ & $\begin{array}{l}H_{c}=\sim 1,000 \mathrm{Oe} \\
B_{m}=\sim 20,000 \text { gauss } \sim *\end{array}$ \\
\hline 屚 系 & $\mathrm{Fe}_{3} \mathrm{O}_{4}, \mathrm{Co}$ 含有 $\gamma-\mathrm{Fe}_{2} \mathrm{O}_{3}$ & $\begin{array}{l}H_{c}=\sim 100 \mathrm{Oe} \\
B_{m}=5,000 \sim 6,000 \text { gauss* }\end{array}$ \\
\hline 系 & $\mathrm{Co}-\mathrm{Ni}, \mathrm{Fe}-\mathrm{Co}-\mathrm{Ni}$ & $\begin{array}{l}H_{c}=\sim 800 \mathrm{Oe} \\
B_{m}=15,000 \sim 24,000 \mathrm{gauss}\end{array}$ \\
\hline 系 & $\begin{array}{l}\mathrm{Fe}(\mathrm{C}) \cdots 80 \sim 90 \text { カーボン } \\
\text { センアロイ (Fe-Ni-Cu-Si-Mn) } \\
\text { スペンサー ( } \mathrm{Fe}-\mathrm{Cr}-\mathrm{Ni}-\mathrm{Mn})\end{array}$ & $\begin{array}{l}\text { 加工性上の制限から磁化 } \\
\text { 特性は劣る }\end{array}$ \\
\hline
\end{tabular}
する.

（c）記録された信号は熱的にむ安定であり，加圧 減磁も少ない。

(d) ${ }_{i} H_{c}$ の温度依存性む小さい.

(e) 転写は少なく SP 比で 58 ～ $61 \mathrm{~dB}$ 亿達する.

(2) $\mathrm{CrO}_{2}$ 粒子

広義のフェライトに属する非鉄酸化金属材料として $\mathrm{CrO}_{2}$ がある. 米国のデュポン社その他で $\mathrm{CrO}_{3}$ や $\mathrm{Cr}-$ $\mathrm{O}_{2} \mathrm{Cl}_{2}$ を出発原料として $\mathrm{CrO}_{2}$ 粒子を得る方法が研究さ れ，最近かなりの性能のものが得られている。 ${ }_{i} B_{m}$ は 7000 gauss 程度であり， ${ }_{i} H_{c}$ は Sb や Te を添加する

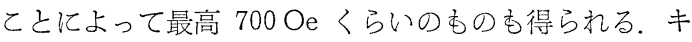
ューリ一点は $116^{\circ} \sim 135^{\circ} \mathrm{C}$ 程度であり，常温からキュー リ一点にかけて ${ }_{i} H_{c},{ }_{i} B_{m}$ 紡急激に低下するという久点 をむっているが，興味深い材料のひとつである，磁場配 向の効果がきわめて大きく $B_{r} /{ }_{i} B_{m}$ が 0.9 にも達するて と，転写が少なく $60 \mathrm{~dB}$ 以上屯得られることなどが，音 声特性からみても有利な特徵といえる。図 3，図4 亿各 種磁性体の ${ }_{i} H_{c}$ と $B_{r \max }$ の温度依存性を示した。

4. 各種磁気テープと音声特性設計の問題点

4.14 ヘッド VTR 用ビデオテープ

現在テレビ放送の音声信号が ON AIR される直前の

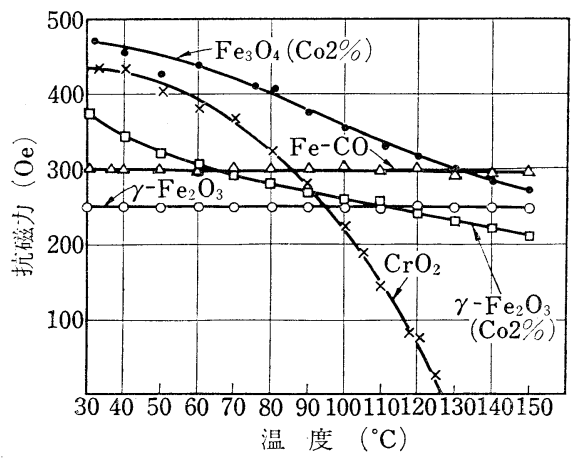

図 3 抗磁力の温度依存性 


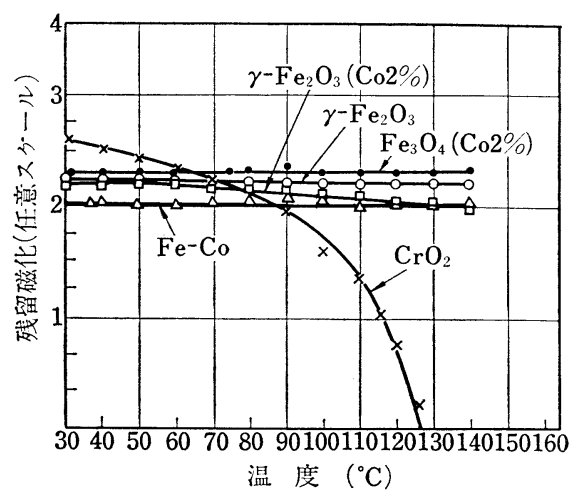

図 4 残留磁化の温度依存性

記録媒体として，4ヘッド VTR 用ビデオテープの使わ れるケースが多くなっている。 フィルム番組，コマーシ ヤルを含めて，すべてのプログラムをいったん 4 ヘッド VTR に記録し，プログラム送出の自動化をはかる傾问 が進むにしたがって，4ヘッドVTR ビデオテープの音 声特性はますますその重要性を増してきている。

4ヘッド VTR 用ビデオテープの最大の特徵は, 同一 磁性面内に映像信号と音声信号とを互いに直角に記録し ていることにある．この両者の要求をどのように具体化 しているかについて述べておきたい.

\section{（1）磁性層の塗布厚さと出力}

図 5 は 4ヘッド VTR 用ビデオテープの磁性層厚と映 像信号, 音声信号の各出力の関係を示したあのである. この図からわかるように，映像記録用に使われる磁性層 はわずか $2 \mu \mathrm{m}$ 以内であり，表 1 に示した塗布厚（10〜 $12 \mu \mathrm{m})$ を必要としているのは主に音声 $\mathrm{SN}$ 比を確保す るためである.

(2) 抗磁力と映像感度, 音声感度の関係

ビデオテープに記録される映像信号は搬送波を $9 \mathrm{MHz}$

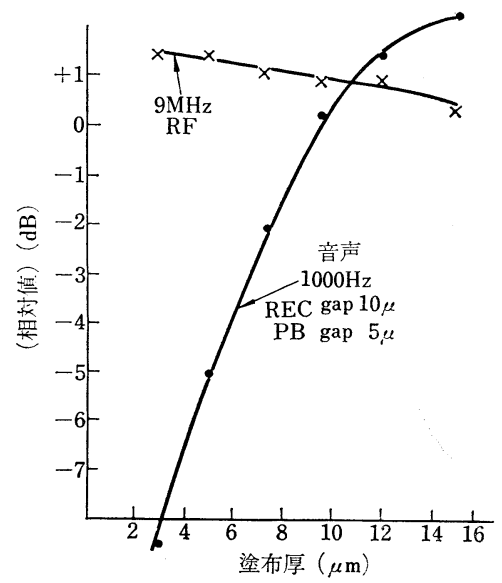

図 5 ビデオテープの塗布厚と映像再生出力 および音声再生出力
として $4 \mu \mathrm{m}$ 前後の短波長となるため, 磁性体の抗磁力 は高いほうが有利であるが，従来テープとの互換性，消 去特性，転写特性など，主に音声特性の制約条件から現 在は $300 \mathrm{Oe}$ 前後に設定されている。図 6 は抗磁力を $110 \mathrm{Oe}$ から $700 \mathrm{Oe}$ まで変えた場合の $9 \mathrm{MHz}$ 無バイア ス記録の最大出力を求めたものであり, 図 7 は抗磁力 250〜502 Oe までのサンプルについて，記録波長 $2 \sim 100$ $\mu \mathrm{m}$ までの最大再生出力を, 抗磁力 $250 \mathrm{Oe}$ のそれ之比 較して表わしたあのである.テープスピードの低速化

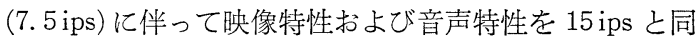
等以上に確保する意味から屯，さらに高抗磁力化の方向 で検討されるべきであろう。

\section{(3) 粒子サイズとの関係}

カラーテレビ信号を高品質で録画再生する SN 比を確 保するために, 表 3 に示した各種磁性体の中でも特に微 粒子 $\gamma-\mathrm{Fe}_{2} \mathrm{O}_{3}$ が採用されている。乙れは音声の $\mathrm{SN}$ 比 を高める方向とも一致しているので，現在ではほとんど すべてのビデオテープがこのタイプである，しかし，音

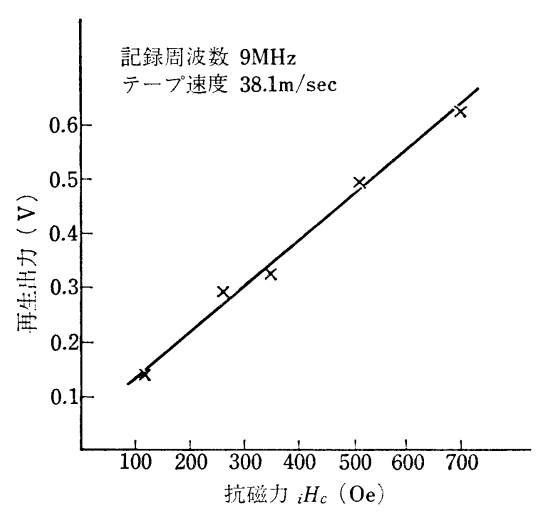

図 6 映像信号 $(9 \mathrm{MHz})$ の最大再生出力と抗磁力の関係

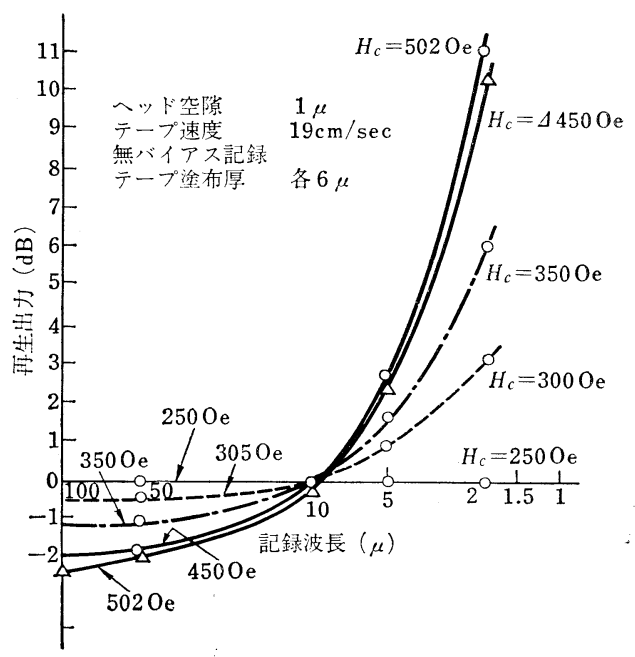

図 7 再生出力の記録波長依存性と抗磁力の関係 


\section{8. テープ録音技術}

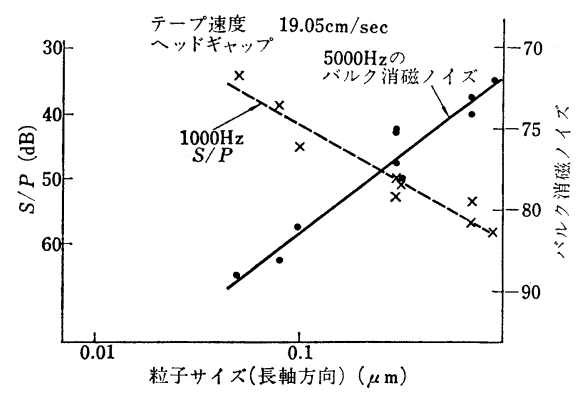

図 8 粒子サイズとバルク消磁ノイズおよび SP 比の関係

声特性の重要なポイントである SP 比が微粒子化ととあ に劣化するので，現状では針状粒子の最小サイズは SP 比を実用上 $48 \mathrm{~dB}$ 以上確保するために，長径 $0.3 \mu \mathrm{m}$ ぐ らいが採用されている(図 8 )。しかし転写効果は平均粒 子サイズが同程度であっても，製造方法が異なると数 $\mathrm{dB}$ も異なることがあることから，ての背反する2つの 要因をさらに良好な領域に追い込める可能性むあるわけ で, 各方面で研究が続けられている。

\section{(4) 磁場配向の最適角度}

4ヘッド VTR 用ビデオテープのあうひとつの重要な ポイントとして磁場配向の設定角度がある. 先に述べた ように，映像信号記録と音声記録とがほぼ直角であるこ とから，まったく片方を優先させるわけにはいかない．

図 9 亿磁場配向角度之 $H_{c}$ 抢よび $B_{r}$ の関係を, 図 10 は磁場配向角度と各周波数の映像感度 (RF 出力), 拉よ び音声感度について求めたあのである. 眓 9 から $H_{c}$ は $45^{\circ}$ 方向に， $B_{r}$ は $0^{\circ}$ 方向にそ机ぞれの最大值をむつて とがわかる，また図 10 からわかるように，映像感度は 短波長記録であるととから，その出力は $0^{\circ} \sim 30^{\circ}$ の範囲 で, $B_{r}$ の減少と $H_{c}$ の増大が相殺されてほぼ同一か, む

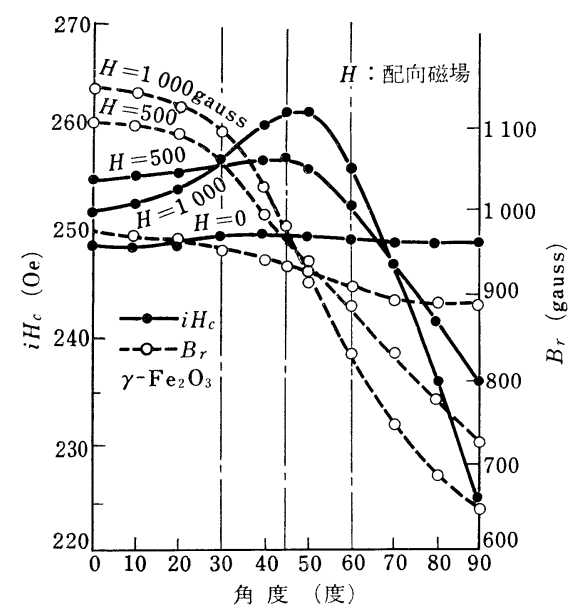

図 9 磁場配向テープに抬ける ${ }_{i} H_{c}, B_{r}$ の角度依存性 (テープ幅方向を $0^{\circ}$ 方向とする)

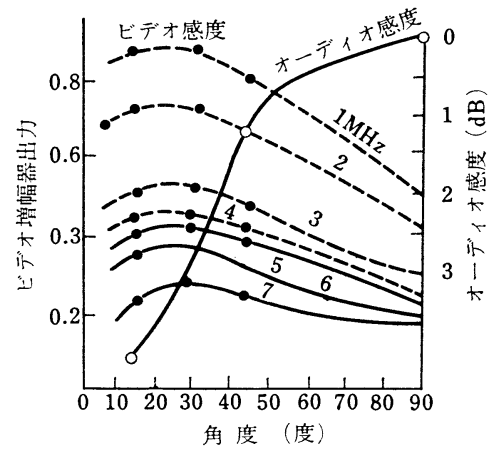

図 10 磁場配向角度とビデオおよびオーディオ感度

しろ角度の深いほうが上がり気味になる。一方, 音声信 号は映像トラックに対して $90^{\circ}$ 回転した方向に，かつ長 波長記録であることから，ほぼ図 9 の $B_{r}$ 值の推移に比 例し，角度が深いほどその出力は增大する。このよう に，映像感度が減少せずしかも音声感度の高い点を求め ようとすれば，その角度は $30^{\circ} \sim 40^{\circ}$ が最も適した值で あることがわかる。

\subsection{MAVTR 用テープ}

音声編集専用作られたヘリカル VTR 用 2 inビデオ テープである。装置およびその特性については本特集 6-2 でくわしく述べられているので，乙こでは主にテー プ側からその必要性能を 4 ヘッド VTR 用テープと比較 しながらふれておきたい。

構造は表 1 亿示したように，一般の 4 ヘッドVTR 用 ビデオテープと同一であるが，磁場配向角度，走行特性 などの点で設計上，製造上の差は大きい．

4 ヘッドVTR 用ビデオテープが，すでに述べたよう に幅方向から $30^{\circ} \sim 40^{\circ}$ 傾けて磁場配向されているのに 対し，MAVTR 用テープのそれは長手方向である. あ ちろんその理由は映像トラックの角度が浅く, 音声トラ ックと同一方向に磁場配向しても別に問題がないからで ある. この結果，後述のように4ヘッド VTR 用テープ にくらべて音声特性上はかなり有利になっている.

MAVTR 用テープにとっての第二の特徽は, 走行安 定性に対する要求性能のシビアさである。一般にヘリカ ル VTR はテープの磁性面とガイドドラムの接触面積が 大きく,このため,ての間の摩擦係数が大きいと走行が不 安定になり，ひどいときには貼り付いてテープが動かな くなることあある。図 11 に4ヘッド VTR 用テープと 比較した摩擦係数の荷重依存性を示した，MAVTR 用 テープが低荷重から高荷重にわたって4ヘッドVTR テ ープよりも摩擦係数が少なく, ヘリカル VTR に対して 走行安定性がより良いととがわかる.

第三の特徴は, 静止画像, スローモーション再生に対 する耐久性である４ヘッド VTR テープでは同一トラ 


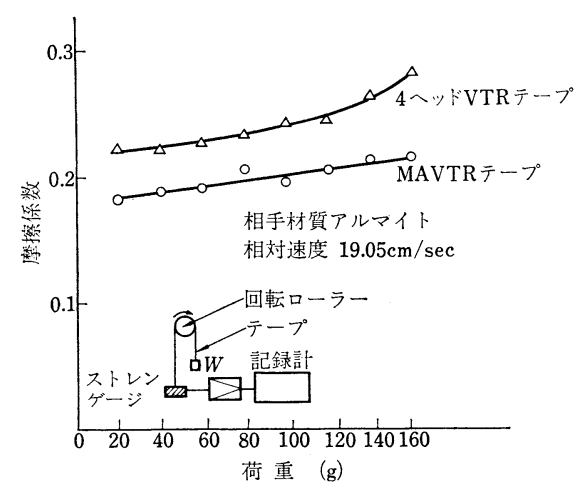

図 11 MAVTR テープと 4 ヘッドVTR テープの摩 擦係数荷重依存性

ックを続けて 2 回以上通るととはありえないが，MAVTR は静止画像再生，スローモーション再生が必要不可 欠である。1 分間に 3,600 回, 約 $20 \mathrm{~m} / \mathrm{sec}$ の速度で 200 $\mu \mathrm{m}$ 前後のヘッドで擦っても磁性層表面が劣化しないバ インダーシステムが要求される．以上のような本質的な 差から，MAVTR 用に特に開発された専用テープが現 在用いられている.

\section{$4.316 \mathrm{~mm}$ 磁気フィルム}

現在 $16 \mathrm{~mm}$ 磁気フィルムの形態には，いわゆるセプ マグ方式とコンマグ方式の 2 種類がある。セプマグは主 として外国映画の吹替用，およびテレビ映画 $(16 \mathrm{~mm})$ に録音および再生用として使用され，コンマグは主とし てニュース番組（報道番組）にそのシングル方式のメリ ットを生かして同時録音などに使用されている。ここで は主にセプマグ方式の磁気フィルムについて，その特 徵, 取扱い上の問題などについて少しくふれておきた い.

\section{(1) パーフォレーション}

ノンパーフォレーションのテープにくらべて同期, 編 集の点でのシンプルさが買われている，機動性と経済性 から，近年いわゆるナグラ方式のようなノンパーフォレ ーション磁気テープを使用する完全な同期方式が採用さ れて急速に普及しつつあるが，編集の問題，キャプスタ ン部の精度，テープの伸縮やスリップなどの問題などか ら，依然としてパーフォレーションタイプもかなり広く 使われている.

一方，磁気フィルム用録音装置むパーフォレーション をそのままテープ送りのメカニズムの一部として使う， いわゆるスプロケット方式から，近年単にパーフォレー ションをテープ送りの信号として使うキャプスタン方式 へ移行しつつあるが，テープの保護のうえからあ好まし い方向といえよう。特性的にもワウ，フラッターに拉い てスプロケット方式が平均 $0.15 \mathrm{Wrms}$ に対し，キャプ
スタン方式は $0.11 \mathrm{Wrms}$ とすぐれている.

\section{(2) ベース厚さ}

磁気フィルムは，他の磁気テープにくらべてベース厚 が著しく厚い(表 1 )。このように愿いベースが使われた のは，映画用銀塩フィルムと同一にし，送り機構もそれ に合わせた歴史的慣習に基づいている，この厚いととに よる影響は，次に述べるようにへッドタッチによる $f$ 特 の互換性を悪化させるほどである。すなわち現在 $16 \mathrm{~mm}$ 磁気フィルムには $5 \mathrm{mil}(127 \mu \mathrm{m})$ ベースと $3 \mathrm{mil}(76 \mu \mathrm{m})$ ベースの 2 種類があるが, 放送用としては $5 \mathrm{mil}(127 \mu \mathrm{m})$ に限られているのもてのためである。つまり $3 \mathrm{mil}$ 厚 の PET ベースの磁気フィルムは，現在の録音再生機が 5 mil 厚の TAC ベース磁気フィルム用に調整されてい る関係上，すべての点で差異があり，番組交換用として は不適当とされている。

図 12 は $5 \mathrm{mil}$ 厚磁気フィルム用に調整されたシネコ 一ダーによって $3 \mathrm{mil}$ 厚磁気フィルムの周波数特性を測 定した例であるが， $7 \mathrm{kHz}$ で 3 4 $4 \mathrm{~dB}$ あ $3 \mathrm{mil}$ 厚ベース のほうが低く出ている。乙れはまったく磁気フィルム本 来の性能によるものではなく，機器（とくにヘッドタッ チ）とのマッチングの問題であって，3 mil 用に調整す れば充分規格内に入ることが確かめられている。この 他， $5 \mathrm{mil}$ 厚に調整された録音再生機に $3 \mathrm{mil}$ 厚を連続 走行させるとパーフォレーションの損傷を受けやすいと と, キャプスタン方式の録音再生機に㧊いてはバックテ ンションの調整，ヘッドの取付角度の調整が必要となる こと, 転写効果が $10 \mathrm{~dB}$ ほど悪化するなどの問題点も含 んでいる。

\section{（3）磁気フィルム取扱い上の注意}

実際に番組交換に使われている $16 \mathrm{~mm}$ 磁気フィルム は，とくにパーフォレーション部が破損していることが 多い，乙れらの原因は機器に装着する際，早送りのため にスプロケットを外す際に傷めることが多いので，乙れ らに注意することが必要である。また塵埃付着によるす りキズ，ヘッドづまりなどあ見られることから，録音へ

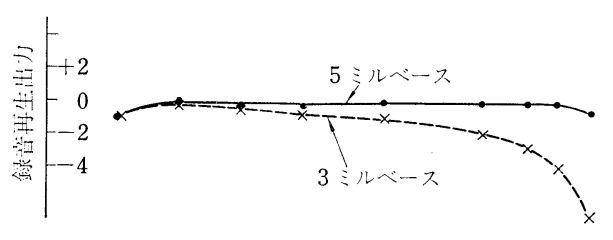

$\begin{array}{cccc}\frac{1}{50} & 100 & 5001000 & 500010000 \\ & & \text { 周波数 } & 1 \mathrm{~Hz})\end{array}$

図 12 磁気フィルムのベース厚の違いによる周波数特性 (ソニー16 T 3 シネコーダ) 
ッド近辺の清掃も忘れてはならないポイントである.

\section{(4) テストフィルム}

放送用 $16 \mathrm{~mm}$ 磁気フィルム録音機および再生機の特 性を規正するむのとしてテストフィルムが作られている ので，その概要を次に示しておく.

\section{種類}

16W フルトラック用

$16 \mathrm{C}$ センタートラック用 NAB

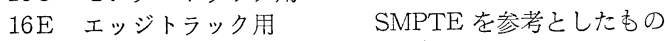

録音内容 $(16 \mathrm{~W}, 16 \mathrm{C})$

第 0 区分 $\quad 7000 \mathrm{~Hz}$

第 1 区分 $\quad 1000 \mathrm{~Hz}$

第2 区分 $\quad 50,1000,5000,7000 \mathrm{~Hz}$

第3 区分

$50,100,200,400,1000$ $3000,5000,7000,10000 \mathrm{~Hz}$

第 4 区分 $7000 \mathrm{~Hz}$

第 5 区分

以上，セプマグ方式の磁気フィルムについて述べてき たが，その使用形態からどうしても操作の複雑さ，画と 音の同期性，設備の不経済性などの欠点をむっており， 画と音が同一フィルムにあるコンマグの需要屯急速に高 まってきている，今後コンマグフィルムの性能の向上と コンマグ専用の機材の改善も望まれている.

\section{5. 各種磁気テープの $6 \mathrm{~mm}$ 幅による音声 特性}

以上述べてきた各種音声記録用磁気テープは，それぞ れ異なった録音機，再生機に装着され使われることか ら，普通示される特性值はそれぞれの録音機の特性と合 成されたものとなっている，乙とでは記録用磁気媒体の 固有の音声特性を比較してみた。

すなわち，各種テープを $6 \mathrm{~mm}$ 幅にスリットし， $6 \mathrm{~mm}$ 幅用録音再生機によってそれぞれの音声特性を比較测定 した. 図 13 に各種磁気テープの再生出力レベルと周波 数特性, 図 14 にバイアス特性, 図 15 にバイアス対ひず み特性, 表 4 に SN 比, SP 比, 出力レベルを示した. これらの図表から特に 4 ヘッドVTR 用テープが，その 配向角度や塗布厚さなどの制約から出力特性が低いレベ

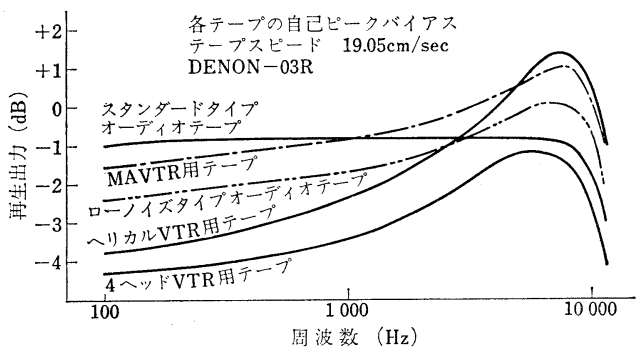

図 13 各種テープの出力レベルと周波数特性 (6 $\mathrm{mm}$ 幅フルトラック)

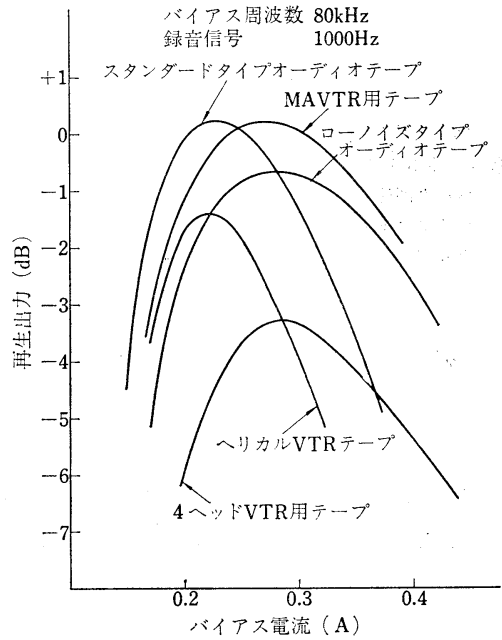

図 14 各種テープのバイアス特性 (6 mm 幅フルトラック)

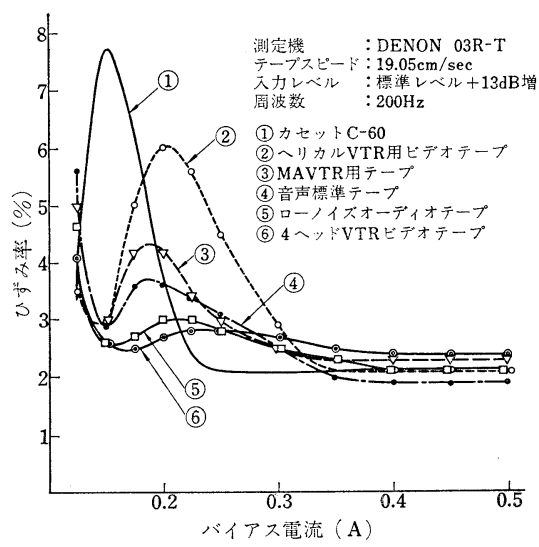

図 15 各種テープのバイアス対ひずみ率カーブ (6 $\mathrm{mm}$ 幅フルトラック)

ルにあることがわかる。

しかし現在，4ヘッドVTR のテープスピードが 38 $\mathrm{cm} / \mathrm{sec}$ と一般の音声記録機器にくらべて 2 倍〜 4 倍と 早いとと，およびテープ自体も磁性体が微粒子であるこ とや表面平滑性の良いことなどによる $\mathrm{SN}$ 比の向上む あって，最終的な音質は実用域に入っている。一方， MAVTR 用テープは，4ヘッドVTR 用テープと異なり 配向上の制約がないため，後者にくらべ出力は 3〜 $4 \mathrm{~dB}$ 高くなっており, 最近の $6 \mathrm{~mm}$ 幅ローノイズタイプと同 等以上の出力レベルが得られている.

\section{6. むす び}

ここに示した各種音声記録用磁気テープの諸条件, 特 性と，それぞれの録音機器のいろいろな制約条件とのバ ランスから最終音質が定められているのであるが，マイ クロホンや電子回路をす含めて音声収録機器の改良が進 
表 4 各種磁気テープの音声特性（テープスピード $19.05 \mathrm{~cm}, \mathrm{DENON}-03 \mathrm{R} 6 \mathrm{~mm}$ 幅フルトラック）

\begin{tabular}{|c|c|c|c|c|c|c|c|}
\hline & 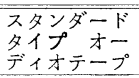 & $\begin{array}{l}\text { イプイズタ } \\
\text { イプオープ } \\
\text { イオテーフ }\end{array}$ & $\begin{array}{l}\mathrm{C}-60 \text { カセッ } \\
\text { ト ( } 6 \mathrm{~mm} \text { 幅) }\end{array}$ & 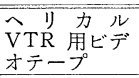 & 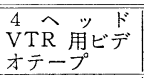 & $\begin{array}{l}\text { MAVTR 用 } \\
\bar{テ} ー フ ゚\end{array}$ & \\
\hline 最高出力レベル（dB) & +0.2 & -0.7 & -0.3 & -1.4 & -3.3 & 0.0 & $1000 \mathrm{~Hz}$ \\
\hline 最高出力を与える電流值 (A) & 0.225 & 0.287 & 0.162 & 0.225 & 0.325 & 0.275 & $1000 \mathrm{~Hz}$ \\
\hline S N 比 (バルク消磁) & 64.4 & 67.8 & 63.4 & 65.8 & 67.6 & 65.4 & 標準再生レベルに対す \\
\hline $\mathrm{S} N$ 比 (バイアスあり) & 57.5 & 60.7 & 57.0 & 60.0 & 63.1 & 60.0 & $\begin{array}{l}\text { 㯖感補正Aカーブ } \\
\end{array}$ \\
\hline S N 比 （感度補正） & 57.7 & 60.0 & 56.7 & 58.6 & 58.8 & 60.0 & $(1000 \mathrm{~Hz})$ \\
\hline $\mathrm{S}$ P 比 & 53.7 & 49.8 & 49.2 & 54.0 & 52.0 & 50.2 & $1000 \mathrm{~Hz}$ \\
\hline
\end{tabular}

むにつれ，磁気テープ自体の性能向上に対する要求む高 まってきている，今後の音声記録用の磁気テープの進む 方向は, SN 比, SP 比を含めたダイナミックレンジの 向上，および低速化，狭トラック化に伴う高密度化が主

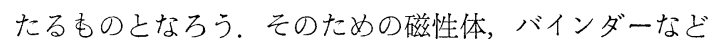
の素材面での改良, 表面平滑化, バックコート化などの
製造加工技術の検討などが各分野で精力的に行なわれて いくであろう。

(昭和 45 年 12 月 11 日受付)

\section{〔参 考 文 献〕}

1) 稲津, 横山，村松，明石，北本，藤山：テレビ誌，21，7(1968)

2) 菅谷, 小林：信学会磁気記録研究会 (1968.6.24)

3) 明不：電学誌, 1 (1969)

昭和 45 年度テレビジョン学会編集委員会

編 集長 石橋 俊夫 $\mathrm{NH}$ 編集理事 青木 昌治 東大 編集理事 加納 顕一 日 電

\section{論文部門委員会}

幹 事 稲津 稔 $\mathrm{N} \mathrm{H} \mathrm{K}$

" 長谷川伸電通大

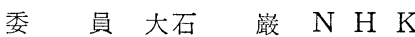
坂田 晴夫 $\mathrm{N} \mathrm{H} \mathrm{K}$

竹下 彊一 NETテレビ 二宮 輝雄 $\mathrm{N} \mathrm{H} \mathrm{K}$ 林義昭 電電公社 村田 重元 N H K 大和 淳二 電電公社 渡部踣 $\mathrm{N} \mathrm{H} \mathrm{K}$ 青木 俊男 日立電子 安達三郎 東北大 生垣 展東芝 稲田謙三 三 洋 岩淵 三郎 N H K 宇田宏 宇宙開発事業団

" 王丸 謙治 N H K
委

"

\section{海外文献部門委員会}

幹事 深津 忠泰 ゼネラル 栗田正一慶大 神瀬 昭 読売テレビ 斎藤 幸平 日電 佐藤 俊夫 フジテレビ 島田聰 ソニ 高梨実 東京 $12 \mathrm{ch}$ 高野 正雄 富士フィルム 武田昭六芝電 時田元昭日 電 中沢康克早大 中村 康平 日大 羽鳥 孝三 北 大 藤尾 孝 $\mathrm{N} \mathrm{H} \mathrm{K}$ 宮崎源太郎 日立 室谷 正芳 電電公社 山田 祥二 静 大 山本 元種 電機 大
幹事今㻕 豊 $\mathrm{NH} \mathrm{K}$ 委員北靖洋 日立 